\title{
The genital atrium armature of some Brazilian sand fly females (Diptera: Phlebotominae)
}

\author{
Emanuelle de Sousa FARIAS ${ }^{1,5}$, Ronildo Baiatone ALENCAR², Sílvia Brandão JUSTINIANO², \\ Rui Alves de FREITAS ${ }^{4}$, Luiz de Souza COELHO², Claudia María RIOS-VELÁSQUEZ 5 , \\ Felipe Arley Costa PESSOA ${ }^{5 *}$ \\ 1 Universidade Federal do Amazonas, Programa Multinstitucional de Pós-Graduação em Saúde, Sociedade e Endemias na Amazônia, Teresina 476 Adrianópolis, 69057-070, Manaus, \\ Amazonas, Brazil. \\ 2 Instituto Nacional de Pesquisas da Amazônia, Coordenação de Biodiversidade, Av. André Araújo, 2.936, Petrópolis, 69067-375, Manaus, Amazonas, Brazil. \\ 3 Centro Universitário Nilton Lins, Coordenação de Pós-Graduação de Biologia Urbana, Av. Professor Nilton Lins, 3259, Parque das Laranjeiras, 69058-030, Manaus, Amazonas, Brazil. \\ ${ }^{4}$ Instituto Nacional de Pesquisas da Amazônia, Coordenação de Sociedade, Ambiente e Saúde, Av. André Araújo, 2.936, Petrópolis, 69067-375, Manaus, Amazonas, Brazil. \\ ${ }^{5}$ Instituto Leônidas e Maria Deane/Fundação Instituto Oswaldo Cruz Amazônia, Laboratório de Ecologia de Doenças Transmissíveis na Amazônia, Rua Teresina 476 Adrianopolis, \\ 69057-070, Manaus, AM, Brazil. \\ * Corresponding author: facpessoa@amazonia.fiocruz.br
}

\section{ABSTRACT}

Phlebotomine sand flies are insects of medical importance. Species in the Neotropical region are highly diverse. Some of these species are considered cryptic species because of their morphological similarity between adult females of different species make identification especially difficult. The aim of this study was to analyze and describe the armature in the genital atrium (AGA) of some adult female sand flies, in order to discover new taxonomic characters that make it possible to distinguish between species that would otherwise be treated as cryptic by analysis of the AGA. The AGA of 16 Phlebotomine sand fly species are described. Distinct differences were found in relation to the shape and size of the armature, the presence or absence of spines on the armature, and the shape, size, and grouping patterns of the spines. These characters made it possible to distinguish between the species studied.

KEYWORDS: cryptic species, taxonomy, morphology.

\section{Armadura do átrio genital de algumas fêmeas de flebotomíneos brasileiros (Diptera: Phlebotominae)}

\section{RESUMO}

Os flebotomíneos são insetos de importância médica. Na região Neotropical existe grande diversidade de espécies. Algumas dessas espécies são consideradas espécies crípticas devido às semelhanças morfológicas entre fêmeas adultas de diferentes espécies, tornando a identificação especialmente difícil. O objetivo deste estudo foi analisar e descrever a armadura no átrio genital (AAG) de algumas fêmeas adultas de flebotomíneos, a fim de descobrir novos caracteres taxonômicos que tornem possível a distinção por análise da AAG entre as espécies que poderiam ser tratadas como espécies crípticas. Foram descritas a AAG de 16 espécies de flebotomíneos. Diferenças distintas foram encontradas em relação à forma e ao tamanho da armadura, a presença ou ausência de espinhos na armadura, e a forma, tamanho e padróes de agrupamento dos espinhos. Esses caracteres tornou possível a distinção entre as espécies estudadas.

PALAVRAS-CHAVE: espécies crípticas, taxonomia, morfologia. 


\section{INTRODUCTION}

Phlebotomine sand flies are insects of medical importance. They play a significant role in the transmission of Leishmania Ross species, the etiological agent that causes leishmaniasis. In the Americas, approximately 500 species have been described; some of these are considered cryptic species because of their morphological similarity (Young and Duncan 1994; Rangel and Lainson 2003).

The genital atrium (Figure 1) is a structure with a thin chitinous membrane containing an armature with small spines; it is present in various invertebrates (Jobling and Lewis 1987). The armature in the genital atrium (AGA) of female sand flies is located between the arms of the furca. The spines of the armature point towards the opening of the atrium, and presumably the armature's function is to assist the movement of eggs as they are laid (Pesson et al. 1994; Valenta et al. 1999). Añes and Tang (1997) observed creased parallel folds flanking the armature of parous females of Lutzomyia migonei (França), but these folds were not found in nulliparous females which suggest that folds are an indicator of age-grading females.

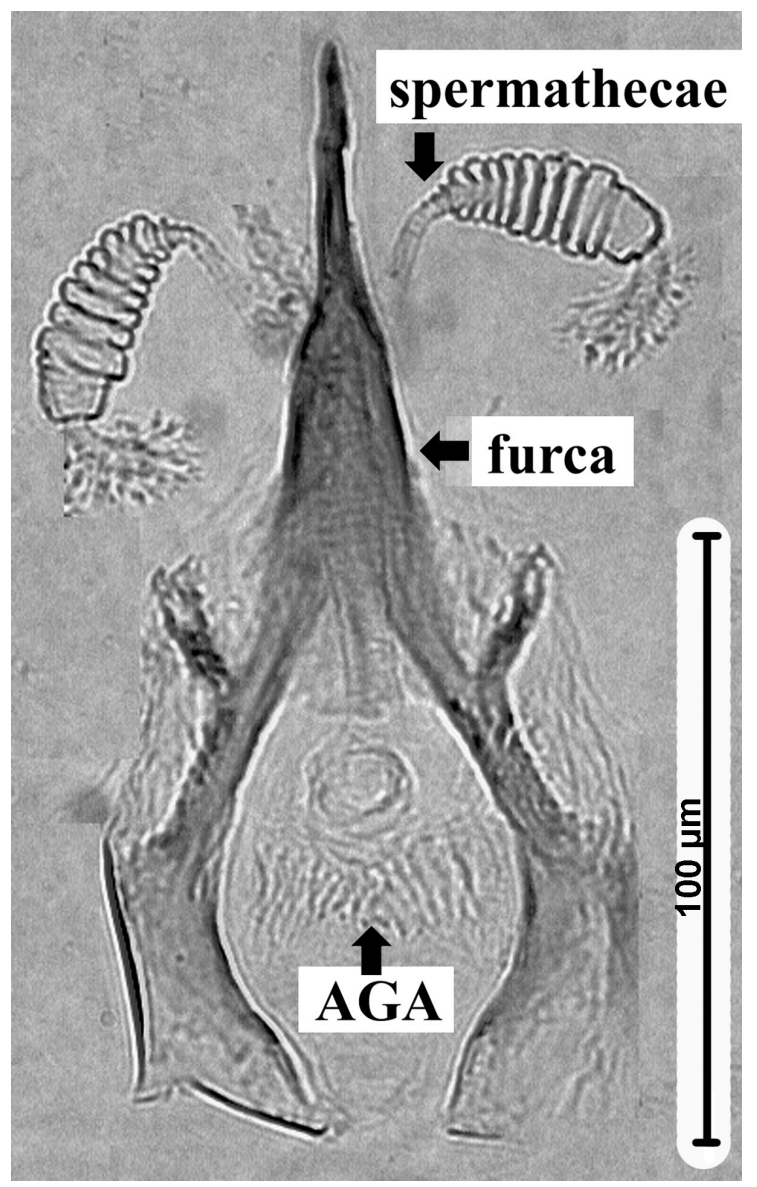

Figure 1. Spermatecae and furca of Lutzomyia flaviscutellata. AGA - Armature in genital atrium, $\mu \mathrm{m}-$ micrometer.
The taxonomic importance of the armature in the genital atrium of phlebotomine sand flies was first examined by Madulo-Leblond et al. (1991). Killick-Kendrick et al. (1994) have shown the presence of the presence of morphology of remarkable character in the genital atria of some Kenyan species of Phlebotomus Scopoli, in the subgenus Larroussius Nitzulescu, and they have suggested that genital armature provides a more effective means of distinguishing between species than do pharyngeal armature.

Very few papers on Old World sand flies have been published in the interim (Pesson et al. 1994; Depaquit et al. 1998; Kakarsulemankhel 2003); even fewer papers have been published on New World sand flies (Valenta et al. 1999; Añes and Tang 1997). The aim of this study was to analyze and describe the armature in the genital atrium of some female sand flies, in order to discover new taxonomic characters that make it possible to distinguish between some species currently considered to be cryptic.

\section{MATERIALS AND METHODS}

Females were field collected from different regions of Brazil, and individually reared under laboratory conditions until F1, according to Killick-Kendrick and Killick-Kendrick (1991) (Table 1). First generation females were used for this study. We used the taxonomical nomenclature proposed by Young and Duncan (1994), and cryptic species identification was confirmed by reference to the morphological characters of reared males. Only nulliparous females were studied in order to exclude any morphological characteristics altered by, or resulting from, the oviposition process (Añez and Tang 1997).

To obtain the furca of each species studied, we separated the last three abdominal segments and placed them in $10 \%$ $\mathrm{KOH}$ for a period of 24 hours. Samples were then washed in $10 \%$ acetic acid, and water, and placed in glycerin for dissection under a stereoscopic microscope. The segments were separated using the standard procedure for isolating segments of the spermathecae. Thin needles were used to break into the segments and open them ventrally, thus exposing the furca within the atrium (Killick-Kendrick et al. 1994). The flies were then mounted in Berlese's fluid.

Specimen images were obtained at the Instituto Leônidas e Maria Deane, using a Digital System (Synoptics ${ }^{\mathrm{TM}}$, Cambridge, UK) adapted to an optical microscope (Leica $\mathrm{DM}^{\mathrm{TM}} 1000$, Frankfurt, Germany). Images were recorded with a digital camera (JVC 3CCD ${ }^{\mathrm{TM}}$, Wayne, USA) and a computer (Lowry et al. 1996). The program Auto Montage 4.0 was used to obtain the final images, and to measure both the length of the furcae and the width of the inner part of the atria. Images of the morphological structures were created by capturing a series of individual images at different focal depths; the focused portions of these images were then stacked to create a composite image. We calibrated 
Table 1. Categories and types of the armature in the genital atrium (AGA) of examined Brazilian phlebotomine sand flies, size in micrometers.

\begin{tabular}{|c|c|c|c|c|c|c|c|}
\hline \multirow{2}{*}{ Specie } & \multicolumn{3}{|c|}{ AGA } & \multicolumn{2}{|c|}{ Comb of spines } & \multirow{2}{*}{ Localities } & \multirow{2}{*}{$\mathrm{N}$} \\
\hline & category & Width & length & Number of spines & length & & \\
\hline Lutzomyia (Lutzomyia) cruzi & 1 & 110 & 30 & $5(4-6)$ & 4.1 & Corumbá, MS (18059’44”S, 57³9’16”W) & 10 \\
\hline L. (L.) longipalpis & 1 & 125 & 40 & $(4-5)$ & 5.5 & Normandia, RR (3052'52"S, 59037'22”W) & 4 \\
\hline L. (L.) longipalpis & 1 & 125 & 40 & $(4-5)$ & 5.5 & Santarém, PA (02²5’30”S, 5443’14”W) & 4 \\
\hline L. (L.) longipalpis & 1 & 112 & 40 & $(4-5)$ & 5.5 & Nízia Floresta, RN (0603’25”S, 3505’52”W) & 3 \\
\hline L. (L.) dispar & 2 & 90 & 41 & $(3-6)$ & 3.7 & Baturité, CE (18059'44"S, 57039'16”W) & 3 \\
\hline L. (Nyssomyia) flaviscutellata* & 1 & 100 & 30 & ungrouped & 9.4 & Novo Airão, AM (2³7’33’'S, 6056’37’'W) & 3 \\
\hline L. (N) olmeca nociva* & 2 & 100 & 40 & - & 8.2 & Novo Airão, AM (2³7’33’'S, 6056’37’'W) & 3 \\
\hline L. (N) anduzei & 1 & 100 & 30 & $(4-7)$ & 3.2 & Novo Airão, AM (2³7’33’'S, 6056’37’'W) & 7 \\
\hline L. (N) umbratilis & 2 & 90 & 40 & $(6-9)$ & 3.1 & Manacapuru, AM (03014'70”S, 60³1'67”W) & 10 \\
\hline L. (N) umbratilis & 2 & 100 & 40 & $(5-8)$ & $s(2.5) \mathrm{I}(3.9)$ & Manaus, AM (030'08”S, 6049'25”W) & 10 \\
\hline L. (N) whitmani & 1 & 110 & 50 & $(4-6)$ & 3.3 & Baturité, CE (4¹9’41'’S, 3853'5’W) & 5 \\
\hline L. migonei migonei group & 2 & 65 & 23 & $(4-5)$ & 4.5 & Baturité, CE (4¹9'41'’S, 3853'5’W) & 6 \\
\hline L. evandroi migonei group & 3 & 120 & 43 & $(4-5)$ & 4.5 & Nízia Floresta, RN (0603’25”S, 3505’52”W) & 5 \\
\hline L. lenti migonei group & absent & absent & absent & Absent & absent & Baturité, CE (419'41"'S, 3853’5”W) & 8 \\
\hline L.carmelinoi migonei group & 3 & 140 & 60 & $(5-7)$ & 4.5 & Santarém, PA, (02²5’30”S, 5443’14”W) & 8 \\
\hline L. (Psychodopygus) wellcomei & 1 & 130 & 42 & $(2-4)$ & $\mathrm{s}(4.3) \mathrm{I}(6.8)$ & 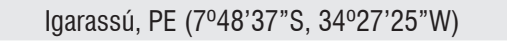 & 2 \\
\hline L. (Pintomyia) fisheri & 4 & 108 & 37 & $(3-7)$ & 4.7 & Baturité, CE (4¹9’41'’S, 3853'5’W) & 3 \\
\hline L. (Evandromyia) inpai & 2 & 113 & 40 & $(9-12)$ & 4.3 & Manacapuru, AM, (03014'70”S, 60³1'67”W) & 3 \\
\hline L. (Pressatia) choti & 2 & 104 & 30 & $(+10)$ & 4.1 & Igarassú, PE (7048’37”S, 34²7’25’W) & 3 \\
\hline
\end{tabular}

Category 1 , slightly concave anterior edge and convex posterior edge; Category 2, partially straight anterior edge and concave posterior edge; Category 3 , slightly convex anterior edge and straight posterior edge; category 4, straight edges.** spines are not grouped in horizontal lines, but individualized in horizontal rows. Localities- AM = Amazonas State; CE = Ceara State; MS = Mato Grosso do Sul State; RN = Rio Grande do Norte State; PA = Pará State, Brazil. N: number of examined individuals, $\mathrm{S}=$ smallest spines, I=largest spines.

the image program with the help of a Zeiss calibration slide. All plates were produced using a image editor (Adobe Photoshop ${ }^{\mathrm{TM}}$ ).

We conducted an intensive search for previously unidentified characters in the genital atria of 16 sand fly species comprising six subgenera and one species group. The characters selected for analysis were: the shape, length, and width of the armature; the presence or absence of spines; the shape, length, and distribution of spines; and the number of spines per comb.

In the species studied, armature in the genital atria were divided into four categories determined by shape and size, and were further differentiated according to the length and width of spine-set groups. The shape of the area where the armature in the genital atrium is located was classified into four categories: Category 1, slightly concave anterior edge and convex posterior edge; Category 2, partially straight anterior edge and concave posterior edge; Category 3, slightly convex anterior edge and straight posterior edge; category 4, straight edges. The specimens used in this study were deposited in the Biological Collection at the Instituto Leônidas e Maria Deane - Fundação Instituto Oswaldo Cruz Amazônia.

\section{RESULTS}

The species analyzed in this study were Lutzomyia cruzi (Mangabeira), L. longipalpis (Lutz and Neiva), L. dispar
Martins and Silva, L. inpai Young and Arias, L. wellcomei (Fraiha, Shaw and Lainson), L. choti (Floch and Abonnenc), L. evandroi (Costa Lima and Antunes), L. fischeri (Pinto), L. olmeca nociva Young and Arias, L. umbratilis Ward and Fraiha, L. whitmani (Antunes and Coutinho), L. migonei, L. lenti (Mangabeira), L. carmelinoi Ryan, Fraiha, Lainson and Shaw, L. anduzei (Rozeboom) and L. flaviscutellata (Mangabeira).

Differences in AGA morphology were observed between females of L. cruzi and L. longipalpis, both classified as category 1. The populations of L. longipalpis (Figures 2B and 2C) possessed AGA of greater length and width, and a higher number of spine sets than L. cruzi (Figure 2A). Differences in AGA morphology were observed in the population of $L$. longipalpis from Rio Grande do Norte State. This population possessed more numerous spine combs, and exhibited less variation in the width and length of spines than did the other population of $L$. longipalpis that we examined. L. dispar (Figure 2D) was the other species examined in the Lutzomyia França subgenus; it exhibited a spine-set pattern similar to that of $L$. longipalpis, but its shape was classified as category 2 (Table 1 ).

The AGA of L. umbratilis was classified as category 2. The two populations exhibited distinct morphology (Table 1). Females of L. umbratilis from Manacapuru (Figure 3C), Amazonas State, showed more abundant spine sets than those found in the population from Manaus (Figure 3D). In the 
Manacapuru population, spines in the same set were of similar size and sets were spaced closely together (Figure 3C). In the Manaus population, spines in the same set varied in size, with the smallest spines in the middle and the largest spines on the margins of the AGA; spine sets were less abundant and spaced farther apart (Figure 3D).
The AGA of $L$. anduzei was similar to that of L. umbratilis, but there were some differences in shape (L. anduzei, category 1; L. umbratilis, category 2), and there were differences in the abundance of spine sets. L. anduzei (Figure 3A) had fewer spine-set groups than L. umbratilis. Lutzomyia whitmani (Figure 3B) possessed a wider and longer AGA than the other

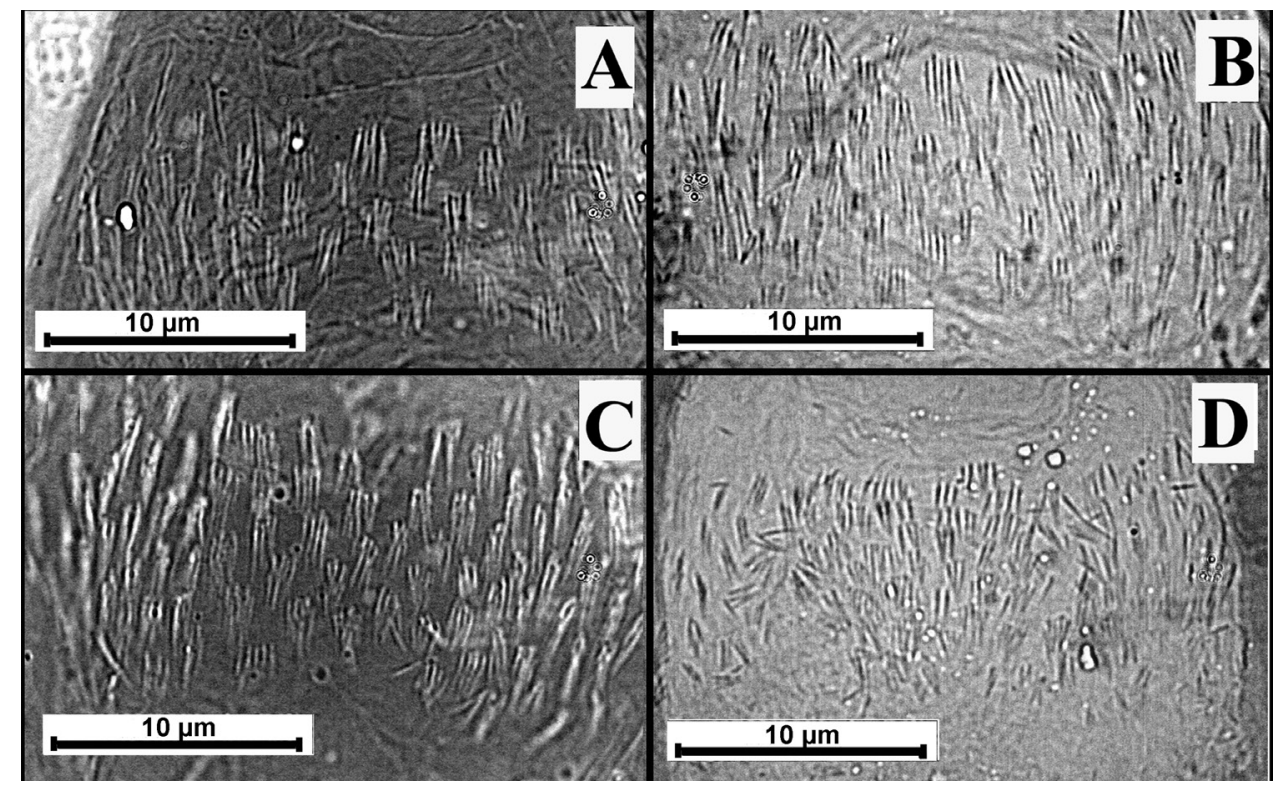

Figure 2. Armature of genital atrium of Lutzomyia; A - Lutzomyia cruzi, B and C - Lutzomyia longipalpis from different populations: B - Rio Grande do Norte population, C - Roraima population, D - Lutzomyia dispar, $\mu \mathrm{m}$ - micrometer.

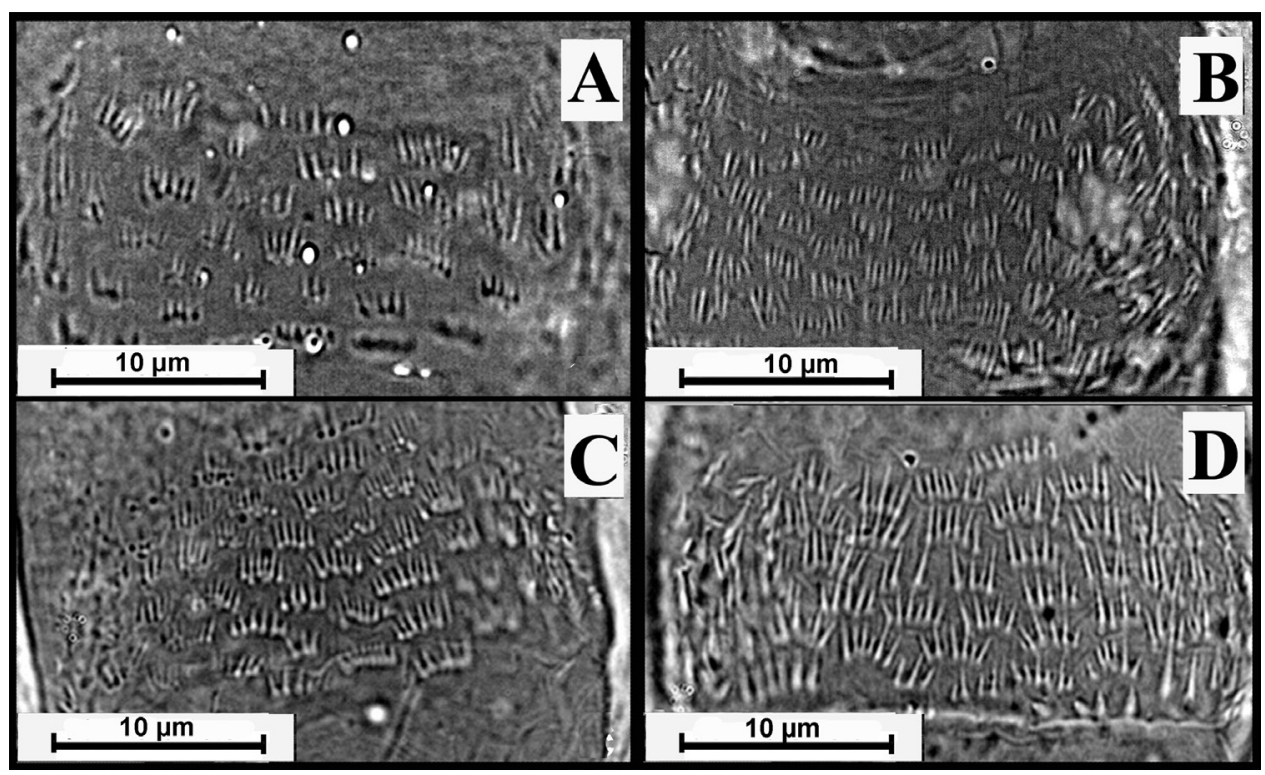

Figure 3. Armature of genital atrium; A - Lutzomyia anduzei, B - Lutzomyia whitmani, C and D - Lutzomyia umbratilis from different populations: C - Manacapuru population, and $\mathrm{D}$ - Manaus population, $\mu \mathrm{m}-$ micrometer. 
species of the subgenus Nyssomyia Barretto that we examined, and its spine-sets occurred in small groups (category 2).

In L. flaviscutellata and L. olmeca nociva, both of the subgenus Nyssomyia, the AGA exhibited spines that were isolated from each other, and that were larger than the spines of the other species examined. In L. flaviscutellata, the AGA was classified as category 1 , and it exhibited hair-like spines distributed in transverse rows (Figure 4A). On the other hand, in L. olmeca nociva, the AGA was classified as category 2; its spines were not distributed in rows, but they were present in large numbers, and they had a wider base that tapered towards the tip (Figure 4B).
The AGA of L. carmelino $i$ was classified as category 3 (Figure 5C). Spines were not observed in the atrium of $L$. lenti (Figure 5D). This absence of spines is a useful character for distinguishing between the females of these two species. The other two species of the migonei group, L. migonei (Figure 5A) and L. evandroi (Figure 5B), were distinguishable by the relative size of their AGA genital atria. The AGA genital atrium of $L$. evandroi was almost twice the size of $L$. migonei, and the shape of the AGA of L. evandroi was classified as category 3 (Table 1).

The AGA of L. inpai (Figure 6B) and L. choti (Figure $6 \mathrm{~A})$ were similar, having the same shape (category 2), and

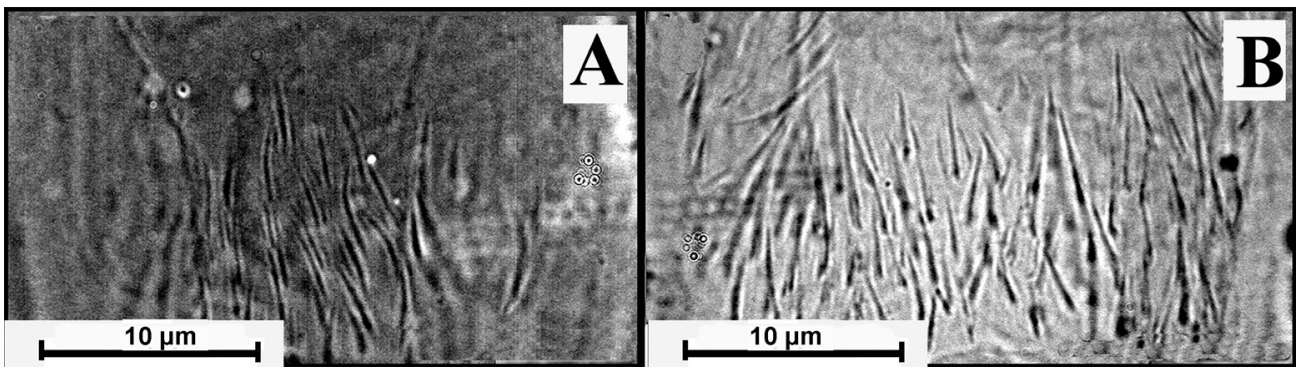

Figure 4. Armature of genital atrium; A - Lutzomyia flaviscutellata and B - Lutzomyia olmeca nociva, $\mu \mathrm{m}$ - micrometer.
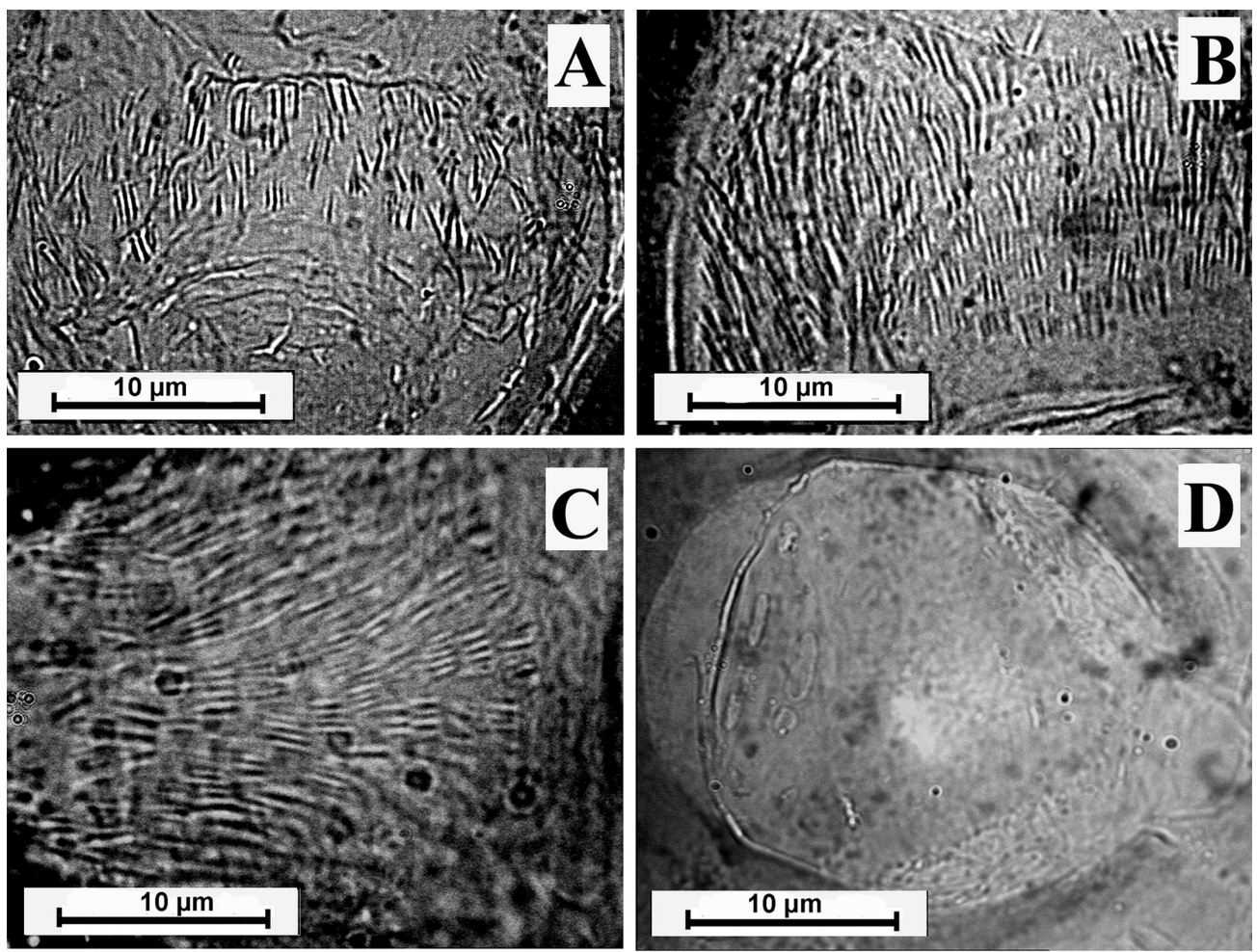

Figure 5. Armature of genital atrium; A - Lutzomyia migonei, B - Lutzomyia evandroi, C - Lutzomyia carmelinoi, and D - Lutzomyia lenti. $\mu$ m - micrometer. 

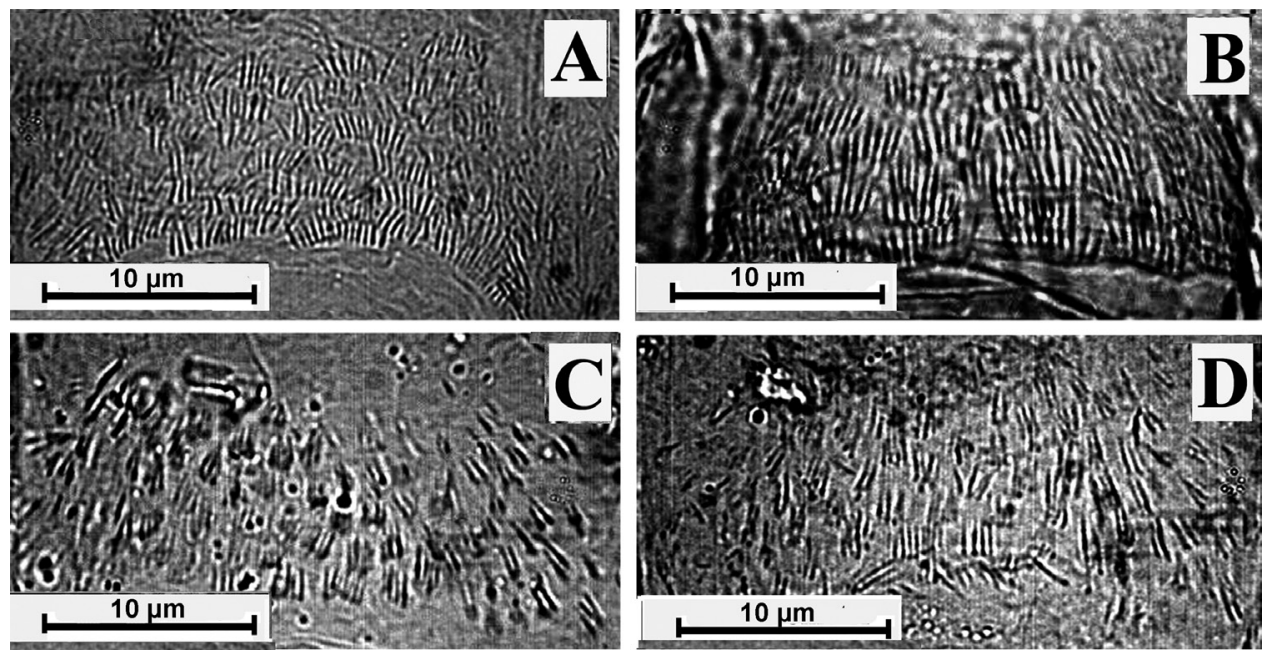

Figure 6. Armature of genital atrium; A Lutzomyia choti, B - Lutzomyia inpai, C - Lutzomyia fischeri, and D - Lutzomyia wellcomei, $\mu$ m - micrometer.

exhibiting large serial groups of nine or more spines. The AGA of $L$. wellcome $i$ was classified as category 1 ; its spines were long and curved, they varied in size, and they occurred in pairs or in groups (Figure 6D). Lutzomyia fischeri, included in the subgenus Pintomyia Costa Lima, was classified as category 4; its spines were curved and of uniform size, and its spine-comb groups were close together (Figure 6C).

\section{DISCUSSION}

In this study, we observed a high degree of variability in the AGA morphology of intra and inter subgenera, and species group. L. cruzi and L. longipalpis are vectors of Leishmania infantum Nicolle, and the females of both species are considered indistinguishable (Young and Duncan 1994); however, differences were observed in the AGA morphology of these species.

Differences were also observed in the AGA morphology of two populations of $L$. umbratilis that are separated from each other by the Rio Negro. Arias and Freitas (1978) suggested that the Negro and Amazonas Rivers could be geographical barriers separating L. umbratilis populations. Lainson (1988) suggested that $L$. umbratilis could represent a species complex since it has not been observed transmitting $L$. (V.) guyanensis in the southern region of the Amazon River. Justiniano et al. (2004) studied the biology of L. umbratilis populations from each side of this river system. Specimens were reared under laboratory conditions, and significant differences were found in the life cycle, fecundity, fertility, and adult longevity of specimens originating from different sides of the river. This suggests that some intrinsic biological features have evolved as the result of geographical isolation created by the Rio Negro. Scarpassa and Alencar $(2012,2013)$ analyzed cytochrome oxidase I sequences of mitochondrial DNA from populations of $L$. umbratilis inhabiting the margins of river banks that are located on opposite sides of the Negro and Amazonas river system, in the Central Brazilian Amazon. They found genetic diversity revealing two distinct clades. These two genetic lineages may represent an advanced speciation stage suggesting the presence of distinct species within $L$. umbratilis. Differences in AGA morphology may provide new information to reinforce the hypothesis that $L$. umbratilis is a species complex.

In Pará State, L. wellcomei is a vector of Leishmania braziliensis Vianna (Lainson et al. 1994). This species has been collected in some areas of the Brazilian Atlantic Forest in the states of Ceará (Queiróz et al. 1994) and Pernambuco (Brandáo-Filho et al. 1997), located in the northeastern region of Brazil. The traits found in the L. wellcomei population from Pernambuco (Figure 6D) are similar to those found in L. wellcomei populations from the states of Ceará and Pará (Queiróz 1995).

Lutzomyia carmelino $i$ is very similar to $L$. lenti. According to Young and Duncan (1994) these species exhibit slight differences in the length and shape of their genital filament tips a trait used to distinguish the males. Ryan et al. (1986) distinguished these species by comparing the ratio of common sperm duct width to individual sperm duct width. Pessoa et al. (2008) found morphological differences between the mature larvae of both species. The AGA of $L$. carmelino $i$ is classified as category 3 , and spines were not observed in the atrium of $L$. lenti (Figure 5D). This absence of spines is a useful character for distinguishing between the females of these two species.

The spines of the AGA in L. flaviscutellata and L. olmeca nociva do not occur in groups or combs (Figures $4 \mathrm{~A}$ and $4 \mathrm{~B}$ ). 
These characters support Galati's proposal $(1995,2003)$ to include both species in genus Bichromomyia Artemiev.

The AGA of $L$. choti and L. inpai are similar (Figures 6A and 6B). These species are included in the subgenera Pressatia Mangabeira and Evandromyia Mangabeira, respectively. Galati (2003) considered Pressatia and Evandromyia, together with Trichopygomyia Barretto to be sister groups, the AGA would be considered a new sinapormorphy to the clade.

The armature in the genital atrium is a useful character in taxonomy and it should be included as an important trait in future descriptions of Phlebotomine sand fly species. It must also be included in future taxonomic reviews of sand fly taxa, especially in cases where there are suspected siblings, or morphologically similar species.

\section{ACKNOWLEDGMENTS}

Emanuelle S. Farias received an MSc scholarship from Coordenação de Aperfeiçoamento de Pessoal de Nível Superior - Capes.

\section{REFERENCES}

Añes, N.; Tang, Y. 1997. Comparison of three methods for agegrading of female Neotropical phlebotomine sandflies. Medical and Veterinary Entomology, 11: 3-7.

Arias, J.R.; Freitas, R.A. 1978. Sobre os vetores da leishmaniose cutânea na Amazônia Central do Brasil. 2. Incidência de flagelados em flebótomos selváticos. Acta Amazonica, 8: 387-396.

Brandão-Filho, S.P.; de Carvalho, F.G.; de Brito, M.E.; Almeida, F. de A.; Nascimento, L.A. 1997. American cutaneous leishmaniasis in Pernambuco, Brazil: eco-epidemiological aspects in 'Zona da Mata' region. Memorias do Instituto Oswaldo Cruz, 89: 445-449.

Depaquit, J.; Léger, N.; Ferté, H. 1998. The taxonomic status of Phlebotomus sergenti Parrot, 1917, vector of Leishmania tropica (Wright, 1903) and Phlebotomus similis Perfiliev, 1963 (Diptera - Psychodidae). Morphologic and morphometric approaches. Biogeographical and epidemiological corollaries. Bulletin of the Society of Pathology Exotic, 91: 346-352.

Galati, E. A. B. 1995. Phylogenetic systematic of Phlebotominae (Diptera, Psychodidae) with emphasis on American groups. Boletin de la Direccion de Malariologia y Saneamiento Ambiental, 35: 133-142.

Galati, E.A.B. 2003. Classificação de Phlebotominae. In: Rangel, E.F. and Lainson, R. (Eds), Flebotomineos do Brasil, Fiocruz, Rio de Janeiro, 23-51p.

Jobling, B.; Lewis, D. J. 1987. Anatomical drawings of biting flies. (Eds) Wellcome Museum of Medical Science, London, 119 p.

Justiniano, S.C.B.; Chagas, A.C.; Pessoa, F.A.C.; Queiroz, R.G. 2004. Comparative biology of Lutzomyia umbratilis (Diptera, Psychodidae) of Central Amazonia, Brazil, under labratory conditions. Brazilian Journal of Biology, 64: 227-235.

Kakarsulemankhel, J.K. 2003. Sandfly (Diptera, Psychodidae, Phlebotominae) fauna of South-Western Pakistan. 1. Diagnostic morphology of Phlebotomus papatasi (Scopoli), Ph. bergeroti (Parrot) and Ph. salehi (Mesghali). Parassitolologia, 45: 103-18.

Killick-Kendrick, M.; Killick-Kendrick, R. 1991. The initial establishment of sandfly colonies. Parassitologia, 33:315-320.

Killick-Kendrick, R.; Tang, Y.; Killick-Kendrick, M. 1994. Phlebotomine sandflies of Kenya (Diptera: Psychodidae). IV. The armature in the genital atrium of female Larroussius as a mean of identification. Annals of Tropical Medicine Parasitology, 88: 433-437.

Lainson, R. 1988. Ecological interactions in the transmission of the leishmaniasis. Philosophical Transactions of the Royal Society of London, 321: 389-404.

Lainson, R.; Shaw, J.J.; Silveira, F.T.; de Souza, A.A.A.; Braga, R.R.; Lshikawa, E.A.Y. 1994. The dermal leishmaniasis of Brazil, with special reference to the eco-epidemiology of the disease in Amazonia. Memorias do Instituto Oswaldo Cruz, 89: 435-443.

Lowry, C.; Shelley, A.J.; Town, B. 1996. New focusing techniques characterize insects for the Natural History Museum in London. Laboratory News, October: A2-A3.

Madulo-Leblond, G.; Killick-Kendrick, R.; Killick-Kendrick, M.; Pesson, B. 1991. Comparaison entre Phlebotomus duboscqi Neveu-Lemaire 1906 et Phlebotomus papatasi Scopoli 1786: etudes morphologique et isoenzymatique. Parassitologia, 33: 387-391.

Pessoa, F.A.C.; Feitosa, M.A.C.; Castellón-Bermúdez, E.G.; Ríos-Velásquez, C.M.; Ward R.D. 2008. Immature stages of two species of Evandromyia (Aldamyia) and the systematic importance of larval mouthparts within Psychodidae (Diptera, Phlebotominae, Psychodinae). Zootaxa, 1740: 1-14.

Pesson, B.; Madulo-Leblond, G.; Killick-Kendrick, M.; Tang, Y.; Killick-Kendrick, R. 1994. The armature in the genital atrium as a new taxonomic character distinguishing females of Phlebotomus papatasi and P. duboscqi (Diptera: Psychodidae). Annals of Tropical Medicine and Parasitology, 88: 539-542.

Queiroz, R.G.; Vasconcelos, I.A.B.; Vasconcelos, A.W.; Pessoa, F.A.C.; Sousa, R.N.; David, J.R. 1994. Cutaneous leishmaniasis in Ceará State in northeastern Brazil: Incrimination of Lutzomyia whitmani (Diptera: Psychodidae) as a vector of Leishmania braziliensis in Baturité Municipality. American Journal of Tropical Medicine and Hygiene, 50: 693-698.

Queiroz, R.G. 1995. Phlebotomine sand flies of a leishmaniasis focus in Baturité, Brazil. PhD Thesis, Departament of Biology, Imperial College of Science, Technology and Medicine, University of London, Ascot, United Kingdom, 175p.

Rangel, E.F.; Lainson, R. 2003. Flebotomíneos do Brasil. Fiocruz, Rio de Janeiro, 367p.

Ryan, L.; Phillips, A.; Milligan, P.; Lainson, R.; Molyneux, D.H.; Shaw, J. J. 1986. Separation of female Psychodopygus wellcomei and P. complexus (Diptera: Psychodidae) by cuticular hydrocarbon analysis. Acta Tropica, 43: 85-89.

Scarpassa, V.M.; Alencar, R.B. 2012. "Lutzomyia umbratilis, the main vector of Leishmania guyanensis, represents a novel species complex", PLoS One, 7: 1-10.

Scarpassa, V.M.; Alencar, R.B. 2013. Molecular taxonomy of the two Leishmania vectors Lutzomyia umbratilis and Lutzomyia anduzei 
(Diptera: Psychodidae) from the Brazilian Amazon. Parasites and Vectors, 6: 2 - 11.

Valenta, D.T.; Añes, N.; Tang, Y.; Killick-Kendrick, R. 1999. The genital atrium as a good taxonomic character to distinguish between species of phlebotomine sandflies (Diptera: Psychodidae) from Venezuela. Annals of Tropical Medicine and Parasitology, 93: 389-399.
Young, D.G.; Duncan, M.A. 1994. Guide to the identification and geographic distribution of Lutzomyia sand flies in Mexico, the West Indies, Central and South America (Diptera: Psychodidae). Memoirs of the American Entomological Institute, 54: 1-881.

Recebido em 28/11/2013

Aceito em 09/06/2014 